\title{
Multicriteria Hybrid Method - ROA, for the choice of generation of renewable sources: case study in shopping centers
}

\author{
Método Hibrido Multicriterio-ROA, para la selección de fuentes \\ de energía renovables: caso de estudio centros comerciales
}

\author{
Alvaro R. Restrepo-Garcés ${ }^{1 *} \quad$ Diego F. Manotas-Duque ${ }^{2} \quad$ Carlos A. Lozano $^{2}$ \\ Recibido 16 de julio de 2015, aceptado 8 de septiembre de 2016 \\ Received: July 16, 2015 Accepted: September 8, 2016
}

\begin{abstract}
In the actual context in which commercial industries need to achieve greater competitiveness through their processes, efficiency is required in the management of electricity. Commercial buildings need solutions that are adequate to their environment and that would mean economic benefits. Given the case in which a commercial building self-generates electricity from renewable energy sources (RES), methods are required for allowing evaluation of alternative sources for generation, taking into account both the RES and methods characteristic uncertainties, which are involved in the process of technology selection. This paper proposes a hybrid method composed by technics of Analytic Hierarchy Process $(A H P)$, the Technique for Order Preference by Similarity to Ideal Solution (TOPSIS), the Theory Real Option Analysis (ROA), the Monte Carlo Simulation (MCS), and the Binomial Method (BM), to select the most adequate technologies for electricity self-generation in Shopping Centers (SCs); it takes into account economic, environmental, technological and technical criteria, within the Colombian regulatory framework. The case study was based on real data for SCs in three different Colombian cities with different meteorological conditions. It was demonstrated that taken into account the real options, the photovoltaic technologies are viable projects to be implemented in the commercial sector. The study is a conceptual contribution and it proposes a methodology for improving the understanding of the complex process of decision making with its application in the evaluation of RES technologies, considering the incentives and the implicit real options in the regulatory framework of a region or a country.
\end{abstract}

Keywords: Uncertainty, self-generation in Shopping Centers, real options, AHP-TOPSIS, normative framework.

\section{RESUMEN}

El contexto actual en el que las empresas comerciales necesitan alcanzar mayor competitividad en sus procesos, demanda eficiencia en la gestión de la electricidad. Los edificios del sector comercial necesitan soluciones acordes con su entorno y que garanticen beneficios económicos. En un escenario en que un edificio comercial autogenere electricidad a partir de fuentes de energía renovables (RES, en inglés), se requieren métodos que permitan evaluar las alternativas de generación, teniendo en cuenta la incertidumbre característica de las RES y de los métodos involucrados en el proceso de selección de las

1 Facultad de Ingeniería Electrónica y Telecomunicaciones. Universidad del Cauca. Popayán, Colombia. Dirección postal: Calle 5 No 4-70. E-mail: arestrepo@unicauca.edu.co; alvarores@gmail.com

2 Facultad de Ingeniería. Universidad del Valle. Cali, Colombia. Dirección postal: Calle 13 N 100-00.

E-mail: diego.manotas@correounivalle.edu.co; carlos.a.lozano@correounivalle.edu.co

* Corresponding author 
tecnologías. Este artículo propone un método híbrido, conformado por las técnicas Proceso de Análisis Jerárquico, Técnica para el Orden de preferencia por similitud con la solución ideal, Análisis de Opciones de Reales, Simulación de Monte Carlo y Método Binomial para seleccionar las tecnologías más adecuadas para la autogeneración de electricidad en Centros Comerciales (SCs), considerando criterios técnicos, tecnológicos, ambientales y económicos y, dentro del marco normativo colombiano. El caso de estudio se realizó con base en datos reales de SCs y en tres ciudades colombianas con diferentes condiciones meteorológicas. Se demostró que aplicando las opciones reales, las tecnologías fotovoltaicas son viables para ser implementadas en el sector comercial. El trabajo es una contribución conceptual y metodológica para mejorar la comprensión de los complejos procesos de toma de decisiones y su aplicación en la evaluación de tecnologías RES, considerando las opciones reales implícitas e incentivos presentes en el marco normativo de un país o región.

Palabras clave: Incertidumbre, autogeneración en centros comerciales, opciones reales, AHP-TOPSIS, marco normativo.

\section{INTRODUCTION}

In 2014 the Colombian Congress approved the 1715 Act (1715A), that established incentives for the promotion and implementation of RES technologies, in order to have better coverage in commercial buildings, homes and industries, through Electricity Self-generation Projects $(E S G P)$. However, there are few studies on the technical and economic viability of RES for self-generation power in the above-mentioned sectors and, there are no studies focusing on the evaluation of this type of projects for the commercial sector in Colombia.

The selection of technologies requires the use of scientific technics in the decision making process, particularly for RES projects, which are influenced by multiple variables and criteria. The planning and reasonable decision-making $(D M)$ in the power generating sector, are strategic activities that are essential in order to achieve competitiveness. However, the complex interactions of different factors and systems associated to RES, makes difficult the design process of ESGP.

The aim of this study is to suggest and apply a hybrid method for the selection and evaluation of the RES technologies, to be implemented in SCs, considering the uncertainty of RES and of the $D M$ process in the selection of alternative technologies. A characterization of $S C s$ was made to determine the type, use of electricity and, the capacity of RES infrastructure installation. Multi-criteria Decision Making (MCDM) technics are used, as well as Discounted Cash Flow (DCF) and, ROA for the selection of the best alternative. In the methodology, the uncertainty of RES (radiation and wind velocity); the process of selection of alternative technologies (which were made with AHP and TOPSIS) and the DCF outputs are modeled through the MCS method. Strategies for the ESGP performance were implemented and the Demand Response Programs (DR) as well as the sale of the traditional power network surplus, is evaluated as real options (RO).

The MCDM techniques require criteria definition for the evaluation of solution alternatives. The alternative most commonly used for the selection of renewable technologies is the economic one. The following are examples of studies that have used these criteria: the Leveled Cost of the Energy (LCOE) [1]; technology investment [2]; the Net Present Value $(N P V)$ [3] and the Maintenance Operation Cost [4]. This study search for in the first place to determine which alternatives are more viable taking into account technical, technological and environmental aspects and, afterwards making an economic evaluation of the selected alternatives. This will be done after considering the stochastic behavior of the project DCF and, of the $R O$ that are presented implicitly within the Colombian regulatory framework. With this procedure, we suppose that the commercial investor would make more efficient decisions, since the final decision will be based on purely economic aspects (which are part of the person's expertise) of a reduced set of alternatives. In addition, unnecessary economic evaluations and calculations of alternatives that have been discarded in the first step of the MCDM are avoided. 
The purpose of $R O A$ is identifying and evaluating the option of a project administrator has to adjust his strategies, according to the uncertainty presented in the Life Cycle Project. The assessment of projects through $R O A$ is based on the decision that could be strongly altered due to irreversibility, uncertainty, and operating margin of the decision maker. The Use of $R O A-D R$ in photovoltaic projects (PV) has been implemented in: residential $P V$ (off-grid PV) [5]; residential $P V$ projects connected to the network [6] and in big projects of power supply [7] and [8]. In Colombia, ROA has been applied in: [9] using DCF-ROA and MCS to assess the option of delaying the investment in an Wind farm taking into consideration tax incentives from the Decree 2755 of 2003. According to [10] it has emerged a great boom in the application of $R O A$ in power generating projects in recent years which demonstrate its potential and flexibility in the projects assessment that include capital assets in the energy sector. The $R O$ are defined in this paper using a risk-neutral valuation method, according to [11].

The study is a conceptual and methodologic contribution, which looks for improving the understanding of the complex process of $D M$ and, its application in the evaluation of RES technologies in commercial buildings, considering the incentives and the implicit real options in the regulatory framework of a region or a country.

The application of MCDM-ROA considering the RES is not wide; its specific application for the evaluation of ESGP considering the implicit $R O$ in the regulation and, in the commercial sector, has no precedent.

The case study is defined from a detailed characterization of the SCS and it is applied to a medium size $S C$, which it is evaluated according to weather conditions in three Colombian cities.

The rest of the study presents the following sections: 2) Methodology; 3) Case Study; 4) Results; and 5) Conclusions.

\section{METHODOLOGY: HYBRID AHP-TOPSIS-DCF-ROA-MCS}

The methodology proposed in this section is based on the use of five techniques: the $A H P$ method is used to define the weights that show the relative importance of criteria considered in the RES power generation. MCS is used to model the stochastic variables. TOPSIS is used to rank the alternatives considered. $D C F$ is used to calculate $N P V$ and $L C O E$ and, the purpose to use $R O A$ is considering the strategic projects flexibility, according to demand management strategies. The methodology proposed is presented on Figure 1.

\section{Analytical Hierarchy Process (AHP)}

$A H P$ is considered as an intuitive method for formulating and analyzing decisions. The method is based on six steps.

The decision-making process is structured as a hierarchy and, it is broken down into several levels (step 1); followed by the definition of criteria $\left(c_{i}\right)$ and alternatives $\left(A_{n}\right)$ (step 2), that can lead to the solution of the problem. The $n$ criteria in the same level are qualified according to the Saaty scale [12] and, a comparison matrix $W$ is obtained [see equation (1)] based on the decision makers' judgment $\left(a_{i j}\right)$ (step 3$)$ and, the researchers want to find a eigen vector of the matrix $\vec{w}=\left[w_{1}, w_{2}, \ldots, w_{n}\right]$ (step 4). Once the vector $\vec{w}$ is obtained, it proceeds to determine the judgments consistency (step 5). The consistency can be measured through the consistency ratio (CR); this value is compared with the Saaty table [12], that presents the aleatory consistency index (CI) as a function of the matrix dimension $n$; if the obtained value is $\leq 0,10$, the consistency matrix is accepted and the weight self-vector is accepted as valid. Once the criteria weight is obtained for each criterion (step 6), the economic criteria could be excluded and the vector $\vec{w}$ is calculated again.

$$
W=\begin{gathered}
C_{1} \\
C_{2} \\
\vdots \\
C_{i}
\end{gathered}\left[\begin{array}{cccc}
c_{1} & c_{2} & \cdots & c_{i} \\
1 & a_{12} & \cdots & a_{n} \\
a_{21} & 1 & \cdots & a_{2 n} \\
\vdots & \vdots & \ddots & \vdots \\
a_{n 1} & a_{2 n} & \cdots & 1
\end{array}\right] .
$$

Where: $a_{j i}=1 /_{a_{i j}} i, j=1, \ldots, n$

Once the vector $\vec{w}$ is obtained without economic criteria, the following step is to determine the values $\left(x_{i}\right)$ of range and average for each criterion (step 7). In this project, the results were modeled according to the average (strategy 1) and with the criteria range 


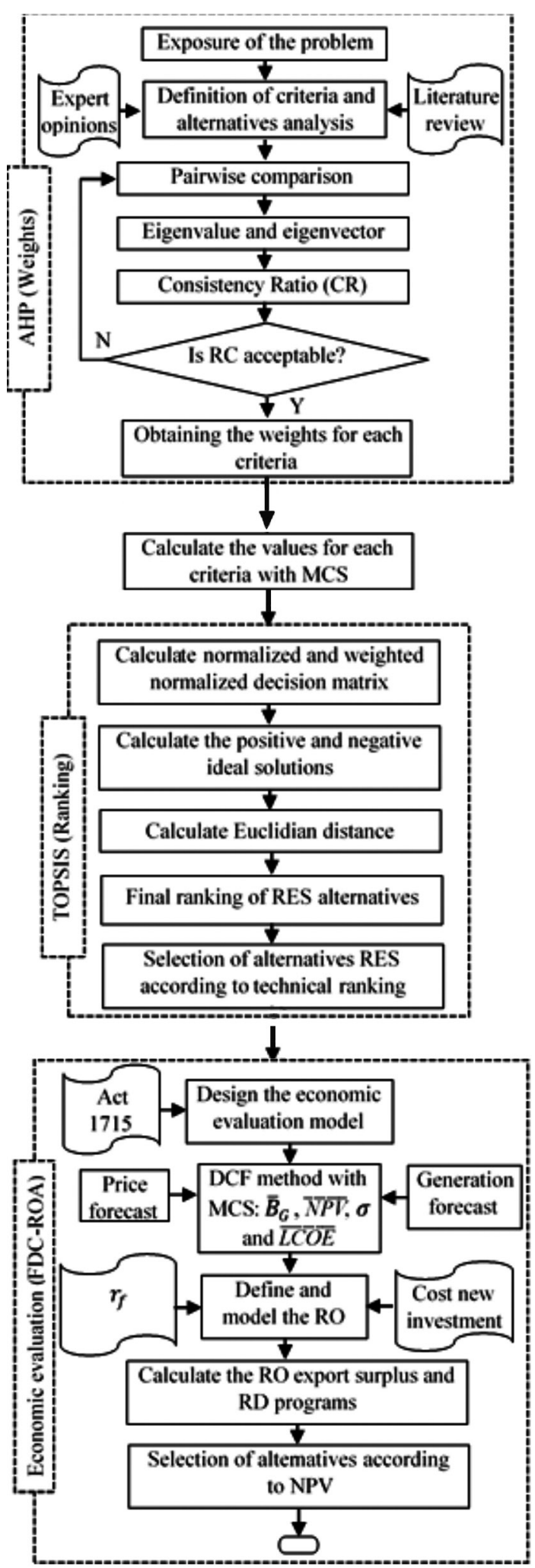

Figure 1. Methodology. Source: the authors. (strategy 2), using $M C S$ according to [13]. This way, results dependability is obtained. The input values for the matrix are simulated with $M C S$, such that $x_{i}$ coul be using the following steps, corresponding to the output data that are named with $\tilde{x}_{i}$.

\section{Technique for Order Preference by Similarity} to Ideal Solutions (TOPSIS)

The underlying principle of this method is based on the idea of choosing alternatives $\left(A_{n}\right)$, that simultaneously have the shortest distance from the positive ideal solution (PIS) and the farthest distance from the negative ideal solution (NIS) (see Figure 2). The PIS maximizes the benefit criteria and minimizes the cost criteria, whereas the NIS maximizes the cost criteria and minimizes the benefit criteria. To apply this method, attribute values must be numeric, monotonically increasing or decreasing, and have commensurable units.

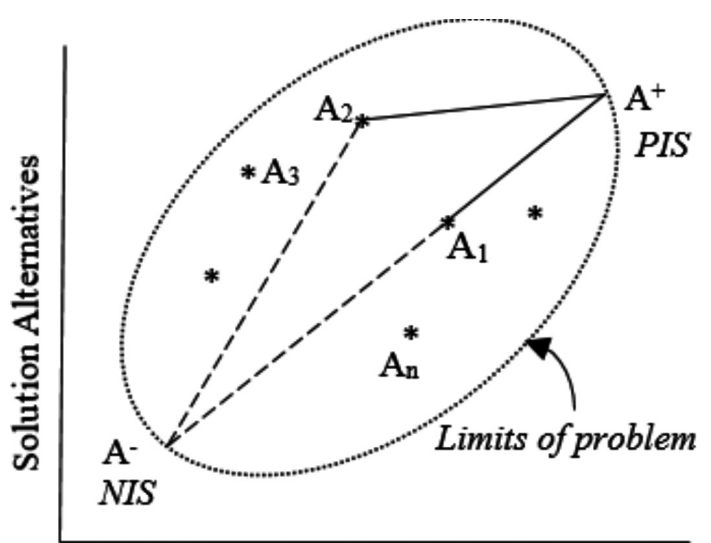

Solution Alternatives

Figure 2. Separation measures for each alternative in TOPSIS. Source: authors.

After obtaining $\vec{w}$ and $\tilde{x}_{i}$ for each alternative, the TOPSIS process is started for which the matrix is normalized and the average matrix is calculated (step 8); PIS and NIS are calculated (step 9); the Euclidian distance is calculated (step 10) and, the alternative ranking is defined (step 11). The last step of multicriteria method, is the selection of the better alternatives according to the ranking, considering only issues such as: space, availability capacity, emissions, efficiency and technology maturity (step 12). Once the alternatives are selected, the following step is to carry out its economic evaluation. For greater 
information on the application of TOPSIS and AHP, it is suggested to refer to [14]

\section{Economic evaluation}

Since the project is evaluated under the Colombian $1715 \mathrm{~A}$ framework, it is required, first, for the economic evaluation model to be defined (step 13) and later, to carry out the process of calculating and simulating of the DCF outputs and, obtain the NPV and $L C O E$ averages-simulations (step 14). At this stage the investor could make a decision, but the flexibility of the life cycle project it has not been considered.

According to the benefits of the $1715 \mathrm{~A}$ for the implementation of ESGP-RES, the $\overline{V P V}$ and $\overline{L C O E}$ means project are computed with equation (2) and equation (3).

$$
\begin{gathered}
\overline{N P V}=\left[\sum_{1}^{t} \frac{\left(B_{i}+\bar{B}_{G}\right)-C_{x}}{(1+W A C C)^{t}}\right]-I_{0}-A D-E D \\
\overline{L C O E}=I_{0}+\sum_{1}^{t} \frac{C_{0}-B_{i}}{\bar{G}_{x}} \\
B_{i}=\sum_{1}^{5} \frac{I_{0} * 50 \%}{(1+W A C C)^{5}}
\end{gathered}
$$

Where $B_{i}$ is the present value of the discounted income tax benefit in the year zero [see equation (3)]; $\bar{B}_{G}$ is the average value of the benefits that result from the demand management; $C_{x}$ are the investment costs; $I_{0}$ is the initial investment; $A D$ is aggregate value tax deduction for investments in $R E S ; E D$ exemption from duties for imports; WACC are capital cost; $C_{0}$ are the costs in $t_{0}$ discounted from the consumer price index and, $\bar{G}_{x}$ is the total average auto-generation of the project.

The $\bar{B}_{G}$ that could result from the project demand management are: 1) the substitution benefits $\left(\bar{B}_{s}\right)$ of service network purchases, which are computed with equation (5) and, 2) the export benefits of surplus $\left(\bar{B}_{e}\right)$, which are calculated equation (6).

$$
\bar{B}_{s}=\sum_{l}^{t} \operatorname{Min}\left(\bar{G}_{x} ; D_{T}\right) * \overline{P P}
$$

$$
\begin{gathered}
\bar{B}_{e}=\sum_{l}^{t} \operatorname{Max}\left[\left(\bar{G}_{x} * \bar{T}_{E}-D_{T} * \bar{T}_{E}\right) ; 0\right] \\
\overline{P P}=F P+m \\
\bar{T}_{E}=F P
\end{gathered}
$$

Where $\overline{P P}$ is the forecasted average purchase price [see equation (7)]; $D_{T}$ is total demand of the commercial building; $F P$ is the forward price; $\bar{T}_{e}$ is the average export tariff for $k W h$ [see equation (8)] and, $m$ is the historic margin between $P P$ and $F P$.

The calculation of $D C F$ according to [15] does not include the uncertainty of $R E S$, therefore, its efficiency is arguable. To contrast that weakness of $D C F$ in this paper, the input variables were modeled with stochastic methods: the forward price $(F P)$ with an Artificial Neuronal Network (NNA), that has already been used by [16]; the solar radiation is modeled with a Normal function and MCS; for the wind speed a Weibull distribution function was used and MCS and, the output of $N P V$ was simulated through $M C S$. After defining the NPV of the alternatives in step 14, the model is elaborated for the calculation of the $R O$ (step 15), which has been before applied by [18].

\section{Real Option Analysis ( $R O A$ ) Theory}

$R O A$ is the application of concepts from financial options valuation for the assessment of real life projects; $R O A$ has proven to be suitable for the assessment of projects under uncertainty. The purpose of $R O$ is to identify and assess manager's options to adjust projects in response to the evolution of uncertainty. That is, $R O$ theory acknowledges the ability of managers to modify their projects with the objective of maximizing profits and minimizing risks in an ever changing world [10].

In general terms, the main problem with $\mathrm{DCF}$ analysis, is that the approach based on $N P V$ rule is not suited for valuing investments in an uncertain environment. If the investment does not need to be made immediately, then the investor has an option but not an obligation to invest in the project. Since for most projects the investment opportunity stays open for a certain period, in which the investment 
can be undertaken, the investment option can be seen as a (perpetual) American option.

Figure 3 shows the logic of a real option valuation. For below break-even prices, the option to invest in the project has a value, unlike the modified $N P V$ framework where the value is zero. As the price rises, the value of the option increases and is actually greater than the intrinsic value of the project $(N P V)$. Options theory gives us guidance on when it is optimal to invest in the project. This should not happen as soon as the NPV becomes positive, but rather when the $N P V$ is significantly positive. Because the investment decision cannot be reversed, we have to consider the opportunity cost of investing now rather than later. Therefore, as the option to invest has value, we should invest when the value of the project is greater than the investment cost plus option to invest.

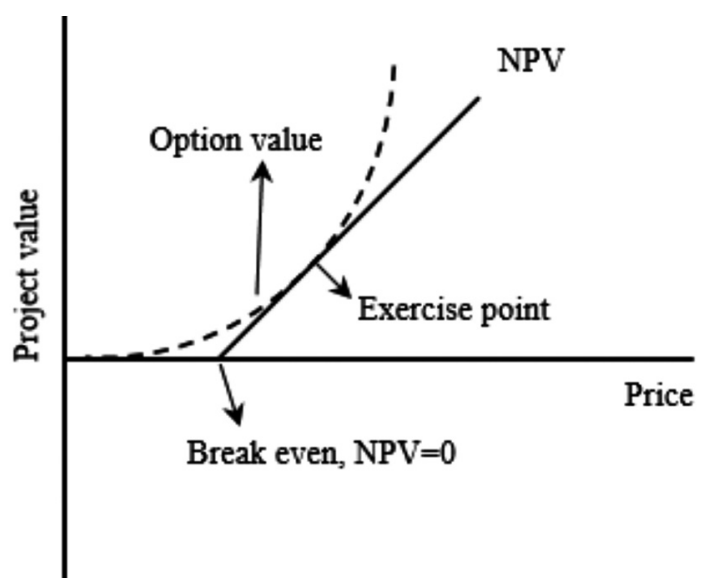

Figure 3. Option Valuation. Source: authors.

Finally, it should be said that $R O A$ does not represent a completely different approach to investment evaluation when compared to $N P V$ analysis. Rather, $N P V$ analysis is encompassed within $R O A$ framework and inputs used in $N P V$ analysis are also used in $R O A$ analysis. Actually, the results obtained under $N P V$ and $R O A$ analysis will be the same if there is no uncertainty. Therefore, $N P V$ can be seen as a special case of $R O A$.

In this project, in order to model the $R O$ implicit in the $1715 \mathrm{~A}$, the programs $R D$ are taking into consideration with $R O$ (step 16), because the investor has the possibility of implementing more technologies, whith the purpose of increasing their benefits. Two $R O$ are considered:

Option $1\left(R O_{e}\right)$, export surplus. The intrinsic value of this option was calculated with equation (9).

$$
R O_{t}=\operatorname{Max}\left[\left(\bar{B}_{e}+\overline{A V}_{0}\right) * u^{t}-K^{\prime} ; 0\right]
$$

Where $\overline{A V}_{0}$ is the average value for the project without surplus sales at moment zero and, $K$ ' the additional cost of investment required for the project broadening. The calculation of $R O_{e}$ with the binomial method was made in two stages, as follows:

Stage 1. The $\mathrm{RO}_{\mathrm{e}}$ value is determined in each of the terminal nodes, according to the Figure 4 and following the equation (10) and equation (11).

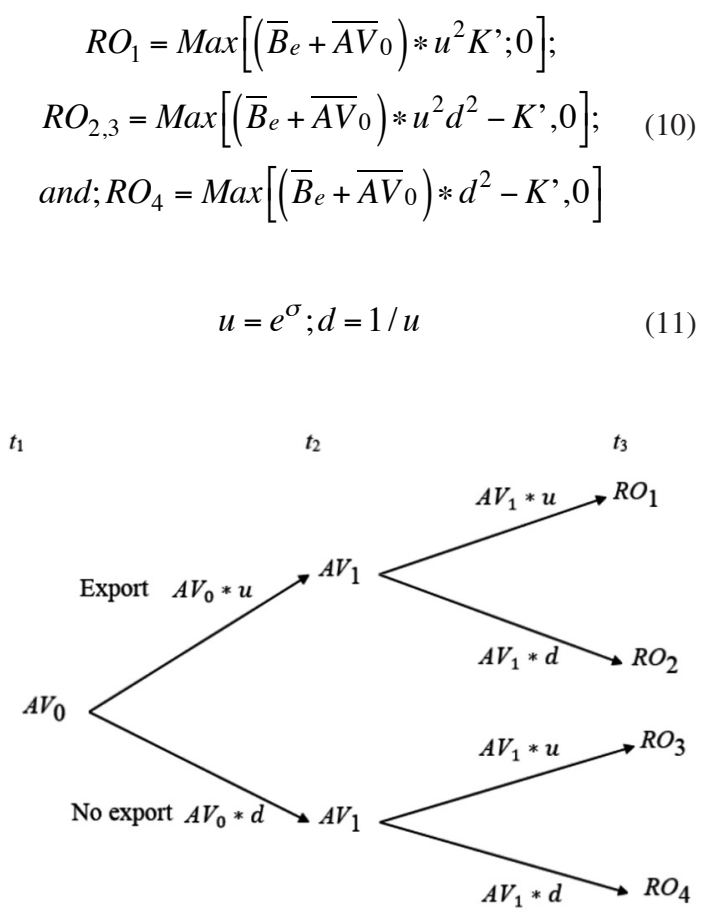

Figure 4. Binomial tree, Option 1. Source: authors.

Where $u$ and $d$ are a random coefficient of increase (up) or decrease (down) with time until expiration and $\sigma$ is the project volatility. The volatility $(\sigma)$ in this project is based on the concept of market asset disclaimer (MAD) [19], according to which, the 
best way to evaluate a project whose value depends on assets traded in the market or a set of sources uncertainty, is based on the same project without considering the uncertainty and any managerial flexibility. In this context the return of the project $(R p)$ is estimated according to equation (12).

$$
R_{p}=\operatorname{In}\left(\frac{A V_{1}+D C F_{1}}{A V_{0}}\right)
$$

Where $A V_{1}=\frac{D C F_{t}}{(1+W A C C)^{t-1}}, D C F_{t}$ is the free cash flow for each period $t$. $A V_{o}$ is the actual value of cash flows at time 0 .

Stage 2. A regressive induction process (see Figure 5) is carried out through the following formulation [see equation (13)]:

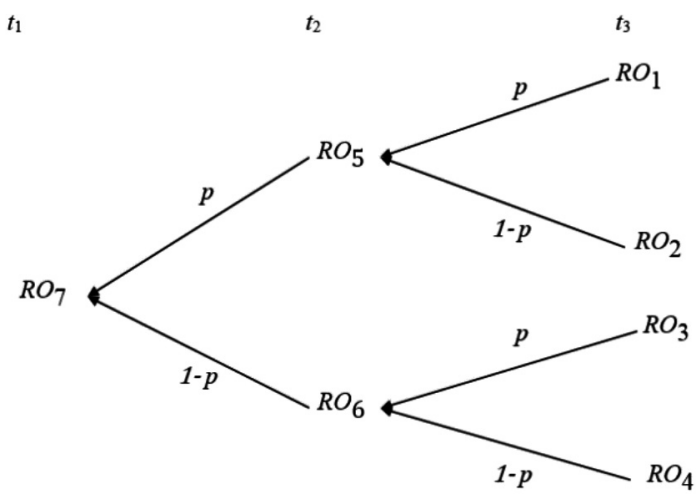

Figure 5. Regressive induction process. Source: authors.

$$
\begin{aligned}
& R O_{5}=\left[\frac{\left(R O_{1} * p\right)+R O_{2} *(1-p)}{1+r_{f}}\right] \\
& R O_{6}=\left[\frac{\left(R O_{3} * p\right)+R O_{4} *(1-p)}{1+r_{f}}\right] \\
& R O_{7}=\left[\frac{\left(R O_{5} * p\right)+R O_{6} *(1-p)}{1+r_{f}}\right]
\end{aligned}
$$

Where $p$ is the probability risk-neutral [see equation (14)], which it is calculated with risk-free rate $\left(r_{f}\right)$. $r_{f}$ is the theoretical rate of return of an investment with zero risk. The risk-free rate represents the interest an investor would expect from an absolutely risk-free investment over a specified period of time.

$$
P=\frac{\left(1+r_{f}\right)-d}{u-d}
$$

The project value in $\mathrm{t}=0\left(R \mathrm{O}_{7}\right)$ is calculated with equation (15).

$$
A V_{t}=N P V_{\text {basic }}+R O_{7}
$$

Where $A V_{f}$ is the project value with flexibility in the year zero and, $N P V_{\text {basic }}$ is the project value without flexibility.

Option $2\left(R O_{R D}\right)$, to participate in programs of Demand Response $(D R)$. Time of Use $(T O U)$ is applied in this case, which, according to [19], consists in the retail price varying in a predetermined way within certain periods (e.g.: peak hours and nonpeak hours, week days and weekends, etc). Two types of tariff are supposed; during non-peak hour $\left(T_{v}\right)$ and during peak hour $\left(T_{p}\right)$ :

$$
\begin{gathered}
T_{v}=\overline{P P} \\
T_{p}=\overline{P P} *(1+s)
\end{gathered}
$$

Where $s$ is a surcharge percentage in the peak hour period.

The economic benefits of the ESGP in the process of calculating of the $D C F$ with $D R$ programs are determined:

$$
\begin{gathered}
\bar{B}_{p}=\operatorname{Min}\left(\bar{G}_{x} ; D_{p}\right) * \bar{T}_{p} \\
\bar{B}_{v}=\operatorname{Max}\left\{\operatorname{Min}\left[\left(\bar{G}_{x}-D_{p}\right) * \bar{T}_{v} ; D_{p} * \bar{T}_{v}\right] ; 0\right\} \\
\bar{B}_{D R}=\bar{B}_{p}+\bar{B}_{v}
\end{gathered}
$$

Where $\bar{B}_{D R}$ is the average value of the benefits and it is substituted in the equation (2), instead of $\bar{B}_{G}$ to determine the $N P V$ of the project. 
The option of participating in DR programs is equal in its process of the $O R_{e}$ calculation, since this also implies the broadening of the project in order to increase the generation. In the equation (10), (9) $B_{D R}$ is substituted for $B_{e}$, and it continues with the same procedure explained for $O R_{e}$.

The next step in the methodology (step 17), consists in evaluating and selecting the alternatives considering only the values for expanded $N P V\left(V P_{f}\right) . L C O E$ is not taken as an indicator for decision, because this was not considered in the analysis of $O R$.

\section{CASE STUDY}

\section{Shopping Centers in Colombia}

The SCs are places dedicated to the commerce of products, distribution of services and, in some cases, to the storage of merchandize. All this, it is done through the leasing and acquisition of commercial spaces. Some of these establishments characteristics are that they are divided in spaces of different size. In Colombia the most common ones are small in size.

The characterization of the SCs is done in the following sections, in order to establish its typology and define a type (SCt).

Constructed area, commercial spaces, and parking lots. In 2014, the gross constructed area for SCs in Colombia was: $4,228.636 \mathrm{~m}^{2}$, with 31.130 commercial spaces [20]. Based on an analysis of 69 SCs (36.3\% of the total), the data of constructed area, number of stores and, parking lots were obtained. The results indicate that the average number of commercial spaces is 200 , the average constructed area is $91,412.70 \mathrm{~m}^{2}$ and the average number of parking lots is 1,024 .

Visitors in shopping centers. A study made in Bogota by [21], finds that the number of visitors to 24 shopping centers during the years 2011 and 2013, was on average 236,571 visitors/year.

Use of energy. The Table 1 shows the consumption by final use for the case study. The greater consumption corresponds to lighting, followed by prime mover and refrigeration.

Energy demand. The behavior in the reference SCS is very similar through time; being that of the first
Table 1. Energy consumption by final use in the $S C$. Source: authors.

\begin{tabular}{|l|r|c|}
\hline \multicolumn{1}{|c|}{ Energy use } & \multicolumn{1}{c|}{$\%$} & kWh/day \\
\hline Direct heat & 8.0 & 242.6 \\
\hline Indirect heat & 0.0 & 0.0 \\
\hline Lighting & 50.8 & $1,540.9$ \\
\hline Refrigeration & 10.3 & 312.44 \\
\hline Air conditioning & 0.0 & 0.0 \\
\hline Prime mover & 26.0 & 788.7 \\
\hline Office Equipment & 3.6 & 109.2 \\
\hline General Services & 0.7 & 21.2 \\
\hline Other uses & 0.6 & 18.2 \\
\hline Average Total Demand & & $3,033.4$ \\
\hline
\end{tabular}

$S C$ the one with the highest consumption. During the day, the demand for electricity increases starting at 17:00 hours and it reaches its peak consumption between 19:00 to 22:00 hrs.

Figure 6 and Figure 7 show the monthly and hourly average demand curves for four SCs of medium size, which do not have air conditioning systems.

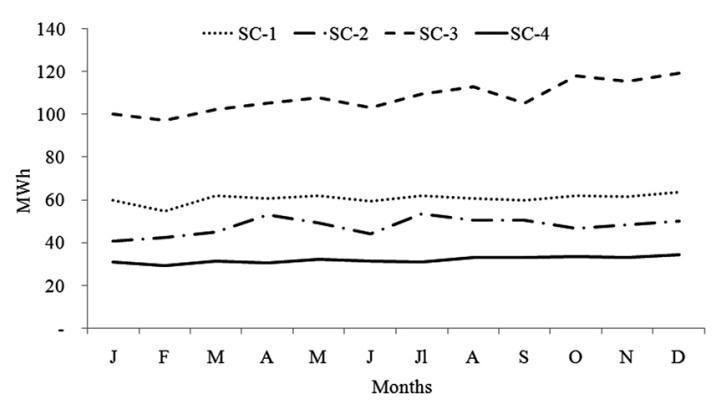

Figure 6. Monthly energy demand for four SCs, year 2013. Source: the authors based on information from the utilities.

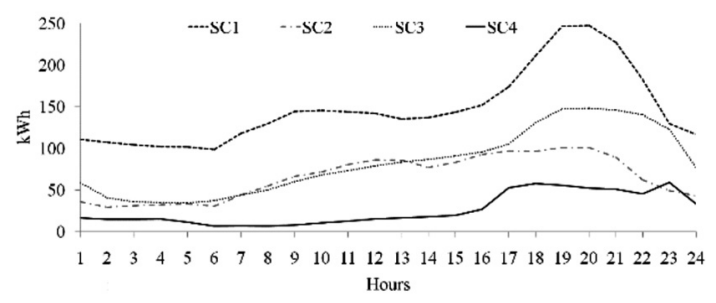

Figure 7. Daily demand curve for $S C$. Source: authors based on information from utilities. 
Purchasing price (PP) of $\mathrm{kWh}$ for the commercial costumer. Figure 8 presents a historical series of monthly electricity prices (August 2010-October 2013). The purchasing price (PP) series total average $S C s$ was $15.80 \phi \mathrm{US} / \mathrm{kWh}$ with a deviation of $2.61 \phi /$ $\mathrm{kWh}$; the forward price (FP) and spot price (SP) total average was of $5.31 \phi / \mathrm{kWh}$ and $6.34 \phi / \mathrm{kWh}$ respectively. The PP was superior to the world average, which according to International Energy Agency (IEA), was $10.12 \phi / \mathrm{kWh}$ for the commercial sector [22].

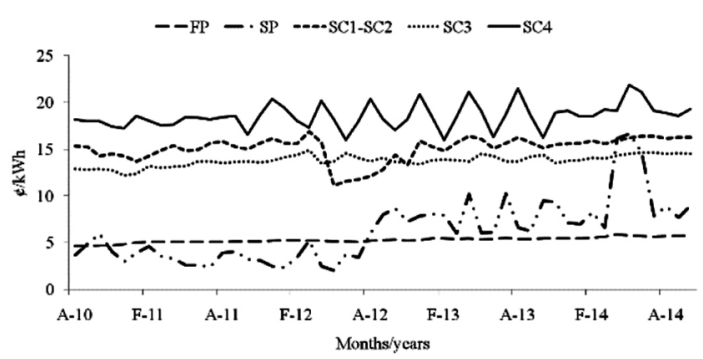

Figure 8. Electricity prices for four SCs. Source: authors based on information from service providers.

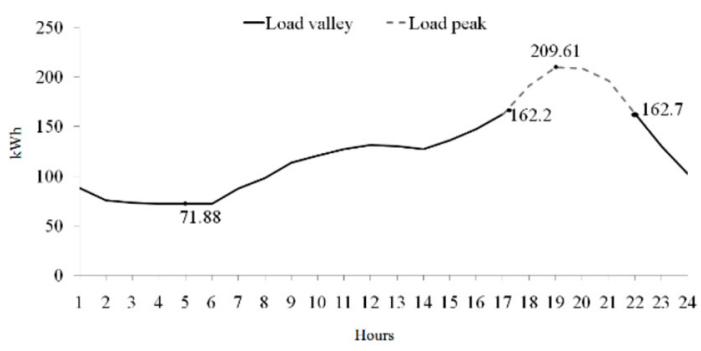

Figure 9. Average hourly demand curve for the $S C(\mathrm{kWh})$. Source: authors based on the utilities report.

The methodology is developed based on the four SCs real data, from which their mean value is obtained: the constructed area is $41,000 \mathrm{~m}^{2}$; number of commercial spaces 150; number of parking lots 460 (parking lot size: $2.3 \times 2.5 \mathrm{~m}$ ), parking total area $3,703 \mathrm{~m}^{2}$ (circulation driveways are included). The average demand (see Figure 9) in $\mathrm{kWh}$ for the $S C$ is: total demand $\left(D_{T}\right)$ 3,033/day; peak hour/day $\left(D_{p}\right) 1,130.77$ and non-peak hour/day $\left(D_{v}\right) 1,902.63$. The demand values correspond to consumption in the common zones of the $S C s$, which are under the $S C s$ administration. The location of the $S C_{t}$ was supposed in three Colombian cities. Their location and altitude is presented in Table 2 .

Table 2. Characteristics of reference cities. Source: authors, based on [23].

\begin{tabular}{|l|c|c|c|}
\hline & Latitude & Longitude & Altitude \\
\hline Pasto & $4.598889^{0}$ & $-74.080833^{0}$ & 2,600 \\
\hline Cali & $3.44^{0}$ & $-76.519722^{0}$ & 1,018 \\
\hline Barranquilla & $10.9638^{0}$ & $-74.796389^{0}$ & 0 \\
\hline
\end{tabular}

\section{RESULTS}

\section{Problem}

Figure 10 presents in a schematic form the exposed problem to deal with and a given solution to the initial problem of selecting a RES technology, for energy self-generation in a $S C$.

Taking into account that $S C$ are located inside cities and in zones of high demographic density, the only alternatives than were considered are Wind $(W)$, biomass $(B)$ and photovoltaic $(P V)$.

\section{Criteria}

The criteria selection was made according with two methods: 1) literature review on the topic presented by [24] and [25] and, 2) consultation with seven experts from the area of renewables in Colombia. Seven criteria were selected (see Figure 10) that were evaluated by ten experts applying the Saaty scale.

The description of criteria is made bellow. At the end of the section in the Table 4, the results of the criteria are presented.

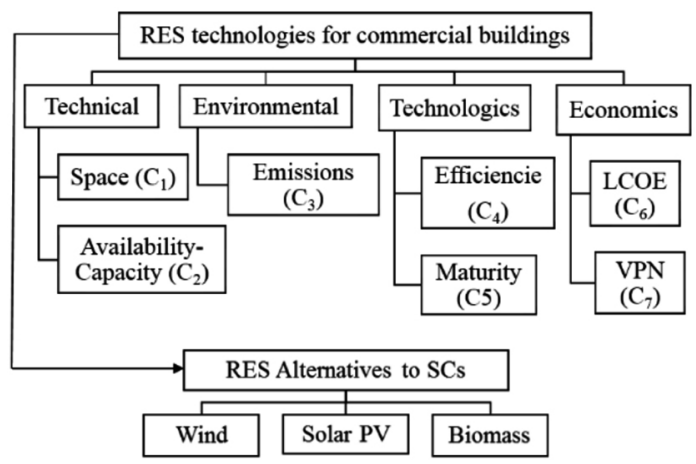

Figure 10. Hierarchy of the problem. Source: authors. 
Use of space $\left(\boldsymbol{C}_{\mathbf{1}}\right)$. This criterion focuses on the area occupied by the technologies in the place that they are disposed for their usage. In this item the results presented by [26] were chosen, since additionally of being current values, they count with the most probable values.

Source availability $\left(C_{2}\right)$. It is the potential of RES found in the location in which the energy generation technologies are being stalled. Starting from the source availability index in every city, the average energy generation $\left(\mathrm{kWh} / \mathrm{m}^{2}\right)$ was calculated modeling its stochastic behavior, with a Normal function distribution and $M C S$.

Biomass. A study made in ten SCs in the city of Santiago de Cali City Hall in 2008, determined that residue average for visitor to a $S C$ is $0.12 \mathrm{~kg} /$ day. We took the value 0.12 and multiply it by the average number of visitors in a $S C$. A weekly production of $552 \mathrm{~kg}$ of residue was obtained. According to [27] only $50 \%$ of residue is usable in energy generation processes, that is, that $276 \mathrm{~kg} /$ week of residue is obtain for combustion. The quantity of usable residue is inferior to the quantity required for the optimum functioning of an energy generating plant, which according to estimates, requires a ton of solid residue to generate between 400 and $600 \mathrm{kWh}$.

Solar radiation. Based on radiation data of [28], the calculations of the energy generation capacity for $S C$ were made, using $260 \mathrm{Wp}$-silicon multicrystal solar panels and, measuring $1.66 \times 0.99$ $\mathrm{m}$. Taking into account the panels size and, the available area of $2,512 \mathrm{~m}^{2}$ (95\% of the total area was taken), from parking lot ceilings, in theory, approximately 1.500 panels $P V$ could be installed. The process of simulation (10.000 runs) with $M C S$ was made, with the number of panels, radiation and, $80 \%$ performance. The results of the $P V$ generation are presented in the Table 3 .

Table 3. Average radiation $\left(\mathrm{kw} \mathrm{h} / \mathrm{m}^{2}\right)$ and wind velocity $(\mathrm{m} / \mathrm{sec})$ in the reference cities. Source: authors based on [23] and [28].

\begin{tabular}{|l|c|c|c|c|c|c|}
\hline \multirow{2}{*}{ Cities } & \multicolumn{2}{|c|}{ Minimum } & \multicolumn{2}{c|}{ Maximum } & \multicolumn{2}{c|}{ Average } \\
\cline { 2 - 7 } & PV & W & PV & W & PV & W \\
\hline Pasto & 3.5 & 0.22 & 4.5 & 0.90 & 4.1 & 1.7 \\
\hline Cali & 4.0 & 0.2 & 5.5 & 0.9 & 4.8 & 1.7 \\
\hline Barranquilla & 4.5 & 2.4 & 6.5 & 6.85 & 5.2 & 4.4 \\
\hline
\end{tabular}

Winds. Table 3 presents the monthly average of wind velocity in the reference cities. According to [29] the minimum required wind velocity for wind generation is between 3.0 and $4.0 \mathrm{~m} / \mathrm{s}$. According to this value, only Barranquilla presents the environmental conditions for the implementation of $W$ technologies.

In order to determine the $W$ generation for the $S C_{t}$, unlike the $P V$ that only takes into account the parking lots parking areas, in this case the calculations were made based on the $S C_{\mathrm{t}}$ parking lot total area. The wind turbine used for this calculations have the following specifications: diameter $5 \mathrm{~m}$; nominal potential $5 \mathrm{~kW}(17 \mathrm{~m} / \mathrm{s})$; starting velocity $2.5 \mathrm{~m} / \mathrm{s}$ and, high $18 \mathrm{~m}$. If the parking lot area is $3,703 \mathrm{~m}^{2}$, (we supposed it is $60.85 \times 60.85$ ) and, it is presumed a predominant wind direction and a aligned line distribution with transversal separation between the turbines, four times the rotor diameter and, six times the diameter of the rotor in direction of the dominant wind, 8 turbines could be installed. The calculation was made with the "swept area method".

After obtaining the data of energy generation for every city and for each technology, the information was unified and, the average daily generation for $m^{2}$ was calculated. The results obtained from the process of MCS are presented in Table 4. In cases where the source is insufficient, a value of zero was given.

Emissions $\left(\boldsymbol{C}_{\mathbf{3}}\right)$. The equivalent carbon dioxide $\left(\mathrm{CO}_{2 e q}\right)$ is a standard unit used to measure the greenhouse gas effect $(G H G)$. Under these criteria, data taken from [30] were considered for the last steps.

Eficiency $\left(\boldsymbol{C}_{4}\right)$. This criterion measures the performance of technology compared to the RES input against the energy generated.

Technology Maturity $\left(\boldsymbol{C}_{\mathbf{5}}\right)$. The concept is based on the recognition that as technology installed increases in capacity, the cost of it decreases once the production capacity doubles. Colombia does not have an established market for the construction of technologies such as photovoltaic cells and $W$ turbines. This type of equipment should be imported. For this reason, it is supposed that the cost will decrease at similar rates reported in previous studies from producing countries. The average values 
Table 4. Criteria values. Source: authors, based on references.

\begin{tabular}{|c|c|c|c|c|c|c|}
\hline \multirow{2}{*}{ Criteria } & & \multirow{2}{*}{ RES } & \multicolumn{3}{|c|}{ Values } & \multirow{2}{*}{ Ref. } \\
\hline & & & Min & Max & Mean & \\
\hline \multirow{3}{*}{$C_{1}\left(\mathrm{~m}^{2}\right)$} & & B & 1,000 & 6,000 & 4,000 & \multirow{3}{*}{ [26] } \\
\hline & & $\mathrm{PV}$ & 10 & 500 & 150 & \\
\hline & & $\mathrm{W}$ & 10 & 1200 & 200 & \\
\hline \multirow{9}{*}{$C_{2}\left(\mathrm{~kW} \mathrm{~h} / \mathrm{m}^{2}\right)$} & \multirow{3}{*}{ Pasto } & B & 0 & 0 & 0 & \multirow{9}{*}{ Author } \\
\hline & & PV & 0.48 & 0.76 & 0.61 & \\
\hline & & W & 0 & 0 & 0 & \\
\hline & \multirow{3}{*}{ Cali } & B & 0 & 0 & 0 & \\
\hline & & $\mathrm{PV}$ & 0.60 & 1.12 & 0.88 & \\
\hline & & $\mathrm{W}$ & 0 & 0 & 0 & \\
\hline & \multirow{3}{*}{ B/quilla } & B & 0 & 0 & 0 & \\
\hline & & PV & 1.20 & 2.23 & 1.74 & \\
\hline & & W & 0 & 0.0581 & 0.006 & \\
\hline \multirow{3}{*}{$C_{3}\left(\mathrm{CO}_{2 \mathrm{eq}}\right)$} & & B & 16.0 & 74.0 & 40.0 & \multirow{3}{*}[30]{} \\
\hline & & $\mathrm{PV}$ & 39.0 & 49.0 & 44.0 & \\
\hline & & $\mathrm{W}$ & 3.0 & 45.0 & 11.0 & \\
\hline \multirow{3}{*}{$C_{4}(\%)$} & & $\mathrm{B}$ & 25.0 & 35.0 & 30.0 & \multirow{3}{*}{$\begin{array}{l}{[34]} \\
{[35]} \\
{[36]}\end{array}$} \\
\hline & & $\mathrm{PV}$ & 10.0 & 30.0 & 25.0 & \\
\hline & & $\mathrm{W}$ & 25.0 & 40.0 & 32.5 & \\
\hline \multirow{3}{*}{$C_{5}(\%)$} & & $\mathrm{B}$ & 2.1 & 9.0 & 5.0 & \multirow{3}{*}{$\begin{array}{l}{[31]} \\
{[32]} \\
{[33]} \\
{[35]} \\
{[36]}\end{array}$} \\
\hline & & $\mathrm{PV}$ & 15.5 & 47.0 & 18.0 & \\
\hline & & W & 6.5 & 8.0 & 7.0 & \\
\hline
\end{tabular}

presented by the IEA [31] and the ranges presented by [32] and [33] taking into account the depth of the studies were taken.

Table 4 shows the value of the criteria, these are the input for the process TOPSIS.

\section{Alternatives Ranking}

The Table 5 presents the results of $\vec{w}$ and $R C$. According to the methodology $\operatorname{LCOE}\left(C_{6}\right)$ and $N P V\left(C_{7}\right)$ economic criteria are excluded and, then the $a_{i}, \vec{w}$ and $R C$ were calculated again. In this two cases $R C$ indicates the consistency of the process performed with $A H P$.

The alternatives evaluation with respect to the source availability criteria that obtained a weight of $40 \%$, yield to discarding technologies that use
Table 5. Eigen vector and RC of the strategies 1 and 2. Source: authors based on the judgment from the experts.

\begin{tabular}{|c|c|c|c|c|c|c|c|c|}
\cline { 2 - 9 } \multicolumn{1}{c|}{} & $\mathbf{C}_{\mathbf{1}}$ & $\mathbf{C}_{\mathbf{2}}$ & $\mathbf{C}_{\mathbf{3}}$ & $\mathbf{C}_{\mathbf{4}}$ & $\mathbf{C}_{\mathbf{5}}$ & $\mathbf{C}_{\mathbf{6}}$ & $\mathbf{C}_{\mathbf{7}}$ & $\mathbf{R C}$ \\
\hline S-1 & 0.06 & 0.32 & 0.10 & 0.09 & 0.15 & 0.11 & 0.17 & 0.032 \\
\hline S-2 & 0.09 & 0.40 & 0.14 & 0.14 & 0.22 & - & - & 0.038 \\
\hline
\end{tabular}

biomass as a source in the three cities and, the wind in the cities of Pasto and Cali. According to what was mentioned, only technologies $P V$ are viable in all three cities and, the wind in Barranquilla. Based on these results, the following steps of the methodology were developed only for Barranquilla. Despite of biomass not reaching the minimum availability values, for methodological reasons, 
this was considered as available in the city of Barranquilla.

As it was mentioned and justified in the methodology description, in order to consider the uncertainty of the criteria values, the ranges of each criteria are modeled with $M C S$, using a uniform distribution for which 100.000 simulations were made using the Risk5.5 software. After the simulation was made, the value that present the greater frequency was chosen and, the value scale was unified applying a scale from 1 to 10 , with 10 being the best performance and 1 the worst. The normalized well balanced matrix results from the two strategies are presented in Figure 11 and Figure 12. It is observed how each alternative RES varies according to the sub-group of criteria being considered and the conditions of resources availability. The area covered by the line in the radar, shows a high (greater area) or low performance (smaller area) of the alternative. In the $P V$ case, the two strategies present the same performance. A similar situation is presented with the wind. The biomass presents a slight difference between the two strategies, as a result that in strategy 1 values equal cero are not considered. The results of the two strategies show consistency in the process and, in this way, it is assured that the data for the following stages are dependable.

The obtained ranking for the two strategies when TOPSIS was applied is presented in Table 6 . In both strategies it is evident the superiority in performance of the $P V$ against the other alternatives. The criteria availability value was $40 \%$. This was a determining factor in the final result.

Table 6. Ranking of alternatives for both strategies. Source: authors.

\begin{tabular}{|l|c|c|}
\hline Alternatives & Strategy 1 & Strategy 2 \\
\hline Biomass & 0.00 & 0.08 \\
\hline PV & 0.69 & 0.74 \\
\hline Wind & 0.31 & 0.27 \\
\hline
\end{tabular}

Just as it was exposed in the methodology, the AHPTOPSIS application phase allowed eliminating the alternatives from the technical stand point. In this case, neither B nor $W$ had any possibility of being implemented in two cities. If the economic criteria had been considered in this phase, its performance would not have been relevant, because these alternatives would have been eliminated or, errors
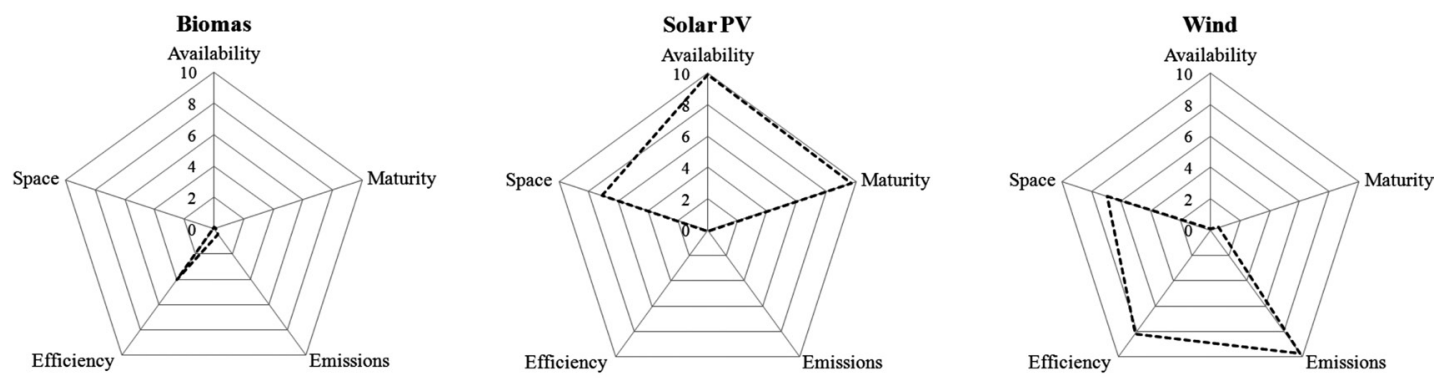

Figure 11. Criteria performance for each alternative, strategy 1. Source: authors.
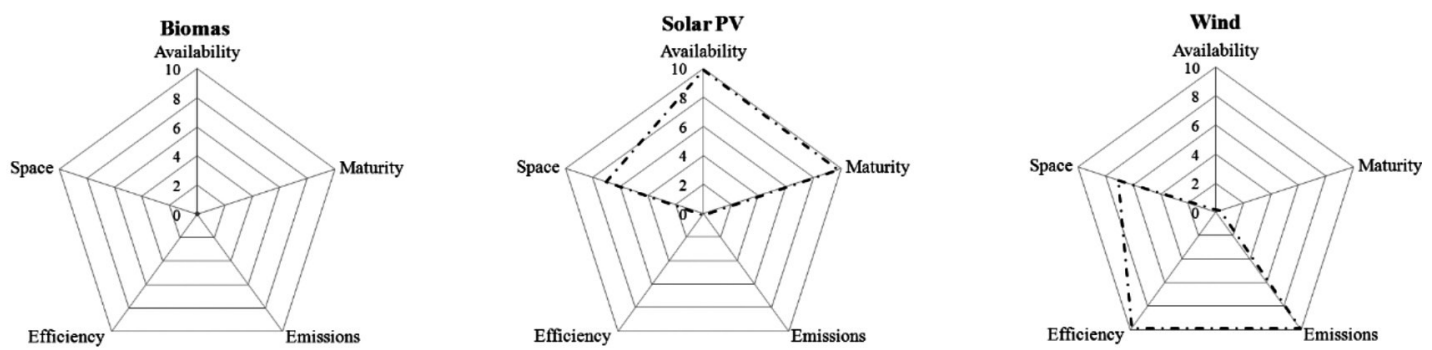

Figure 12. Criteria performance for each alternative, strategy 2. Source: authors 
would be more likely to happen in the final ranking if the economic performance were greater than that of other alternatives. The proposed methodology allows focusing in the economic analysis of a reduced number of alternatives, making this process more efficient.

According to the obtained results with the TOPSIS and for methodological purposes, the economic evaluation of the two best ranked alternatives is presented in the following sections

\section{Economic Evaluation of Alternatives}

A baseline scenario $(B S)$ was defined with the availability of resources of Barranquilla (radiation and wind speed), exhibit in Table 4.750 $P V$ panels, 4 wind turbines and, without incentives of 1715A.

For the calculation of the $D C F$ the following were assumed: a period of ten years; a WACC of $11,5 \%$; and costs of O\&M of $0,4 \%$ of the investment costs equal to the value used by [37]. The mean value of the $D C F$ output that resulted from 10.000 simulations with $M C S$ is presented in Table 7. Figure 13 and Figure 14 present the $N P V$ of the $P V$ and Wind projects. The results indicate that any of them is viable.

If the alternatives analysis were to end in this phase, the results obtained through the $D C F$ method, could indicate to the commercial investor, that should not invest in $P V$ or Wind projects.

\section{Alternatives Value With $R O A$}

With the purpose of analyzing the flexibility of $N P V$, the Binomial Method was used according to economic model, considering the $R O$ and incentives of the 1715A. The $r_{f}$ value for the calculation of ROA, are the TES to ten years: $8.12 \%$ [38]. The other values, are according to baseline scenarios (see Table 7).

Table 7. Results of the $D C F$ from the baseline scenario. Source: authors.

\begin{tabular}{|l|c|c|}
\cline { 2 - 3 } \multicolumn{1}{c|}{} & Solar PV & Wind \\
\hline LCOE & 0.09 & 0.32 \\
\hline NPV $(\$)$ & $(72,797)$ & $(155,513)$ \\
\hline Benefits demand management $(\$)$ & 319,879 & 30,360 \\
\hline Investment & 345,557 & 180,817 \\
\hline AV $(t=1)$ & 273,961 & 22,558 \\
\hline NPV $>0$ & 0 & 0 \\
\hline
\end{tabular}

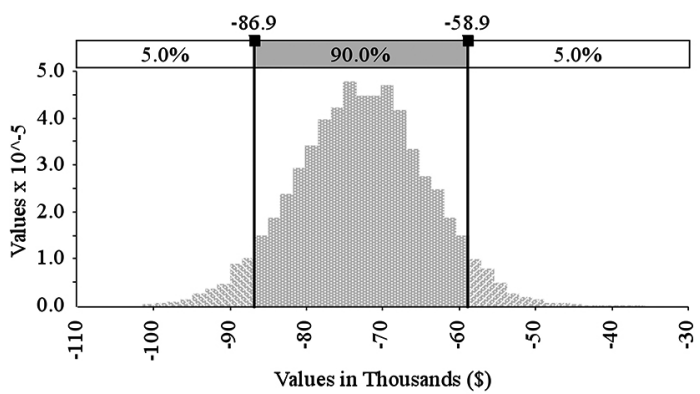

Figure 13. NPV of the baseline scenario of the PV system. Source: authors.

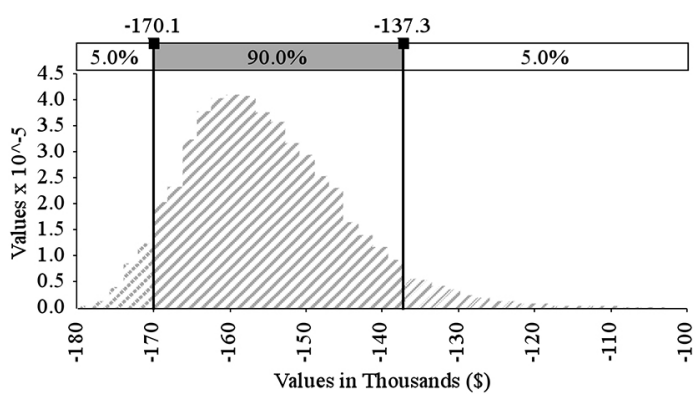

Figure 14.NPV of the baseline scenario for the wind system. Source: authors.

$R O_{e}$. Broaden the generation capacity and export the surplus to the service network at a price equal to $\bar{T}_{E}$. In this case, it is supposed an increase of $100 \%$ in the number of panels $P V(1500)$ and Wind turbines (8) with respect to the baseline scenario.

$R O_{R D}$. Participate in $R D-T O U$. Priority is given to peak hour demand. This situation requires the implementation of storage and control systems. The generation capacity described in $R O_{e}$ is maintained.

When the $R O$ are included, the extended $N P V$ values $\left(A V_{f}\right)$ (see Table 8) acquire positive values, making the $P V$ and $\mathrm{W}-R O_{e}$ viable projects under the conditions evaluated here.

Table 8. Option Values (US\$).

\begin{tabular}{|l|c|c|c|c|}
\cline { 2 - 5 } \multicolumn{1}{c|}{} & \multicolumn{2}{c|}{ PV } & \multicolumn{2}{c|}{ Wind } \\
\cline { 2 - 5 } \multicolumn{1}{c|}{} & $\boldsymbol{R O}_{\boldsymbol{e}}$ & $\boldsymbol{R O}_{\boldsymbol{R} \boldsymbol{D}}$ & $\boldsymbol{R O}_{\boldsymbol{e}}$ & $\boldsymbol{R} O_{R \boldsymbol{D}}$ \\
\hline Aditional $I_{0}$ & 217,988 & 228,155 & 401,976 & 101,929 \\
\hline Aditional Benefits & 294,535 & 337,718 & 584,709 & 159,775 \\
\hline$V P_{f}$ & 273,758 & 166,336 & 130,676 & $(176,526)$ \\
\hline
\end{tabular}


But according to the values obtained in the first stage (see Table 6) and the current values of $V P_{f}$ of $P V$, it is not worth, in this case, to continue to the next phase of the multi-criteria evaluation, that would be: evaluation of alternatives with the TOPSIS method, considering the results of the extended $N P V$ and, according to the $\vec{w}$ of each one presented in Table 5 . This can only be justified, if $P V$ values in any of the economic criteria were lower than those of wind.

\section{CONCLUSIONS}

Unlike the traditional approach that evaluate economic indexes such the $L C O E$ and $N P V$ together with other types of indicators, the proposed methodology evaluates, in the first place, technical, technological, and environmental criteria with the purpose of determining the technical viability of the project. After that, it makes an economic evaluation of only the RES that approved the first step taking into account the flexibility of $N P V$. The procedure allows the project investors make an evaluation MCDM more efficiently. It was demonstrated that the methodology is applicable and provides the investor a lower number of alternatives which would facilitate his final decision.

The ROA technique was used for evaluating the options of exporting surplus of energy generation and participation in DR-TOU programs. In this way, the project negotiation flexibility was considered and the established parameters were evaluated according to the Colombian regulation under which it was demonstrated the viability of the $P V$ and Wind technologies for a certain $S C$. The biomass in $S C s$ is a source that besides not counting with enough volumes for energy generation, showed low performance in the process of evaluation of alternatives.

A methodology was proposed that would consider the participation of Colombian experts in the area of renewable resources for the formulation of criteria, alternatives and judgment of criteria.

The previous study is a conceptual and methodology contribution to improve the understanding of the complex process of decision making and its application in the evaluation of RES technologies considering the incentives and options in the regulatory framework of a region or a country.

\section{REFERENCES}

[1] S.J. Klein and S. Whalley. "Comparing the sustainability of U.S. electricity options through multi-criteria decision analysis". Energy Policy. Vol. 79, pp. 127-149. 2015. DOI:10.1016/j.enpol.2015.01.007

[2] B. Wang, L. Nistor, T. Murty and Y. M. Wei, "Efficiency assessment of hydroelectric power plants in Canada: A multi criteria decision making approach". Energy Economics. Vol. 46, pp. 112-121. 2014. DOI: 10.1016/j. eneco.2014.09.001

[3] J. Mourmouris and C. Potolias. "A multicriteria methodology for energy planning and developing renewable energy sources at a regional level: A case study Thassos, Greece". Energy Policy. Vol. 52, pp. 522-530. 2013. DOI:10.1016/j.enpol.2012.09.074

[4] D. Streimikiene and T. Baležentis. "Multicriteria assessment of small scale CHP technologies in buildings". Renewable and Sustainable Energy Reviews. Vol. 26, pp. 183189. 2013. DOI: 10.1016/j.rser.2013.05.046

[5] E. Martinez-Cesena and J. Mutale. "Assessment of Demand Response Value in Photovoltaics Systems based on Real Options Theory". Power Tech, 2011 IEEE Trondheim, Trondheim. 2011. DOI: 10.1109/ PTC.2011.6019160

[6] O. Sezgen and G. Krishnarao. "Option value of electricity demand response". Energy. Vol. $32 \mathrm{~N}^{\circ}$ 2, pp. 108-119. feb 2007. DOI: 10.1016/j.energy.2006.03.024

[7] I. Wangensteen, A. Botterud and N. Flatabo. "Power System Planning and Operation in International Markets-Perspectives From the Nordic Region and Europe". Proceedings of the IEEE. Vol. $93 \mathrm{~N}^{\circ} 11$, pp. 2049-2059. 2005. DOI: 10.1109/JPROC.2005.857488

[8] F. Kienzle, P. Ahčin and A. Göran, "Valuing Investments in Multi-Energy Conversion, Storage, and Demand-Side Management Systems Under Uncertainty". IEEE Transactions on sustainable energy. Vol. 2 $\mathrm{N}^{\circ}$ 2, pp. 194-202. April, 2012. DOI: 10.1109/ TSTE.2011.2106228

[9] C. Maya, J. Hernández y O. Gallego. "La valoración de proyectos de energía eólica en Colombia bajo el enfoque de opciones reales. Cuadernos de Administración". 
Vol. $25 \mathrm{~N}^{\circ}$ 44, pp. 193-231. 2012. URL: http://revistas.javeriana.edu.co

[10] E. Martínez-Ceseña, J. Mutate and F. RivasDavalos. "Real options theory applied to electricity generation projects: A review". Renewable and Sustainable Energy Reviews. Vol. 19, pp. 573-581. 2013. DOI:10.1016/j. rser.2012.11.059

[11] J.C. Cox, S.A. Ross and M. Rubinstein. "Option Pricing: A simplified Approach". Journal of Financial Economics. Vol. 7, pp. 229-263. 1979. DOI:10.1016/0304-405X(79)90015-1

[12] T. Saaty and L.G. Vargas. "Models, Methods, Concepts \& Applications of the Analytic Hierarchy Process". 1st ed., New York: Springer Science+Business Media,LLC, 2001, p. 6. ISBN 978-1-4614-3597-6

[13] S. Hadian and K. Madani. "A system of systems approach to energy sustainability assessment: Are all renewables really green?". Ecological Indicators. Vol. 52, pp. 194-206. 2015. DOI:10.1016/j.ecolind.2014.11.029.

[14] J.R. San Cristóbal M. "Multi-Criteria Analysis in the Renewable Energy Industry". Springer-Verlag. London, pp. 11-17, 43-48. 2012. ISBN 978-1-4471-2346-0.

[15] L. Shun-Chung. "Using real option analysis for highly uncertain technology investments: The case of wind energy technology". Renewable and Sustainable Energy Reviews, vol. 15, pp. 4443-4450, 15 Septiembre 2011. DOI:10.1016/j.rser.2011.07.107

[16] S. Anbazhagan and N. Kumarappan. "DayAhead Deregulated Electricity Market Price Forecasting Using Recurrent Neural Network". EIEE Systems Journal. Vol. 7 $\mathrm{N}^{\circ}$ 4, pp. 866-872. 2013. DOI:10.1109/ JSYST.2012.2225733.

[17] L. Santos, I. Soares, C. Mendes and P. Ferreira, "Real Options versus Traditional Methods to assess Renewable Energy Projects". Renewable Energy. Vol. 68, pp. 588-594, 2014. DOI:10.1016/j.renene.2014.01.038.

[18] T.A.V. Copeland, "Real options: a practitioner's guide", United Kingdom: Penguin Group, 2001. ISBN: 978-1587991868.

[19] U.S. Department of Energy. "Benefits of Demand Response in Electricity Markets and Recomendations for Achieving them". DOE, 2006. Obtained 12 de May de 2014, from http://energy.gov
[20] ACECOLOMBIA. "Comportamiento de la Industria 2014-2015". Punto Comercial, pp. 29-35, 2014. URL: http//acecolombia.org

[21] C. Gómez G. "Record de Construcción de Centros Comerciales". Portafolio, 2 abril 2014.

[22] IEA. "The Impact of Global Coal Supply on Worldwide Electricity Prices". OECD/ IEA, Paris, 2014a. Available: https://www. iea.org

[23] NASA. "Atmospheric Science Data Center", NASA, 2015. Available: https://eosweb.larc. nasa.gov. [Last access: 17 Abril 2015].

[24] V. Ibáñez-Forés and V. Perez-Belis, "A holistic review of applied methodologies for assessing and selecting the optimal technological alternative from a sustainability perspective". Journal of Cleaner Production. Vol. 70, pp. 1-23. 2014. DOI:10.1016/j. jclepro.2014.01.082

[25] W. Jiang-Jiang, Z. Y.-Y. J. Chun-Fa and Z. Guo-Zhong. "Review on Multicriteria decision analysis and in sustainable energy decision-making". Renewable and Sustainable Energy Reviews. Vol. $13 \mathrm{~N}^{\circ}$ 9, pp. 2263-2278, 2009. DOI:10.1016/j.rser.2009.06.021

[26] M. Troldborg, S. Heslop and R.L. Hough. "Assessing the sustainability of renewable energy technologies using multi-criteria analysis:Suitabilityofapproachfornatio nal-scale assessments and associated uncertainties". Renewable and Sustainable Energy Reviews. Vol. 39, pp. 1173-1184. 2014. 1184. DOI:10.1016/j.rser.2014.07.160

[27] IDAE. "Plan de Energías Renovables 2011-2020". Madrid: Instituto para la Diversificación y Ahorro de Energía. 2011. URL: http://www.idae.es/

[28] UPME-IDEAM. "Atlas de Radiación Solar de Colombia", Bogotá: Ministerio de Minas y Energía-Colombia, 2005. URL: http:// www.upme.gov.co/

[29] IEA. "Tecnology Roadmap Wind Enegy". Paris: OECD/IEA, 2013. Available: http://www.iea. org/Textbase/npsum/ETP2012SUM.pdf

[30] NREL. "Life Cycle Assessment Harmonization Results and Findings", [En línea]. Available: http://www.nrel.gov/analysis/sustain_lca results.html. [Último acceso: 14 April 2015].

[31] REN21, Renewables 2014, GLOBAL STATUS REPORT, Paris: Worldwatch Institute, 2014. ISBN: 978-3-9815934-2-6. 
[32] NREL. "National Renewable Electricity Laboratory". 2015. Available: http://www. nrel.gov/ncpv/images/efficiency_chart.jpg.

[33] A. Evans, V. Strezov and T.J. Evans. "Assessment of sustainability indicators for renewable energy technologies", Renewable and Sustainable Energy Reviews. Vol. 13, pp. 1082-1088. 2009. DOI:10.1016/j. rser.2008.03.008

[34] IEA. "Energy Technology a Perspectives 2012". Pathways to a clean Energy System, Paris: @ OCDE/AIE, 2012. Available:https:// www.iea.org/publications

[35] P. Criqui, S. Mima, P. Menanteau and A. Kitous. "Mitigation strategies and energy technology learning: An assessment with the POLES model". Technological Forecasting, vol. 90, pp. 119-136, 2015. DOI:10.1016/j. techfore.2014.05.005

[36] L. Neij. "Cost development of future technologies for power generation. A study based on experience curves and complementary bottom-up assessments". Energy Policy. Vol. $36 \mathrm{~N}^{\circ}$ 6, pp. 2200-2211. 2008. DOI:10.1016/j.enpol.2008.02.029

[37] F. Bensebaa. "Solar based large scales power plants: what is the best option?". Progress in PHOTOVOLTAICS: Research and Applications. Vol. $19 \mathrm{~N}^{\circ}$ 2, pp. 240-246. 2010. DOI:10.1002/pip.998

[38] Grupo AVAL. "Portal Financiero". 20 marzo 2015. Available: https://www.grupoaval.com/ wps/portal/grupo-aval/aval/portal-financiero. [Last access: 20 Mayo 2016]. 